\title{
Observed changes in temperature and precipitation extremes and their association with atmospheric circulation patterns on the Qinghai-Tibet Plateau
}

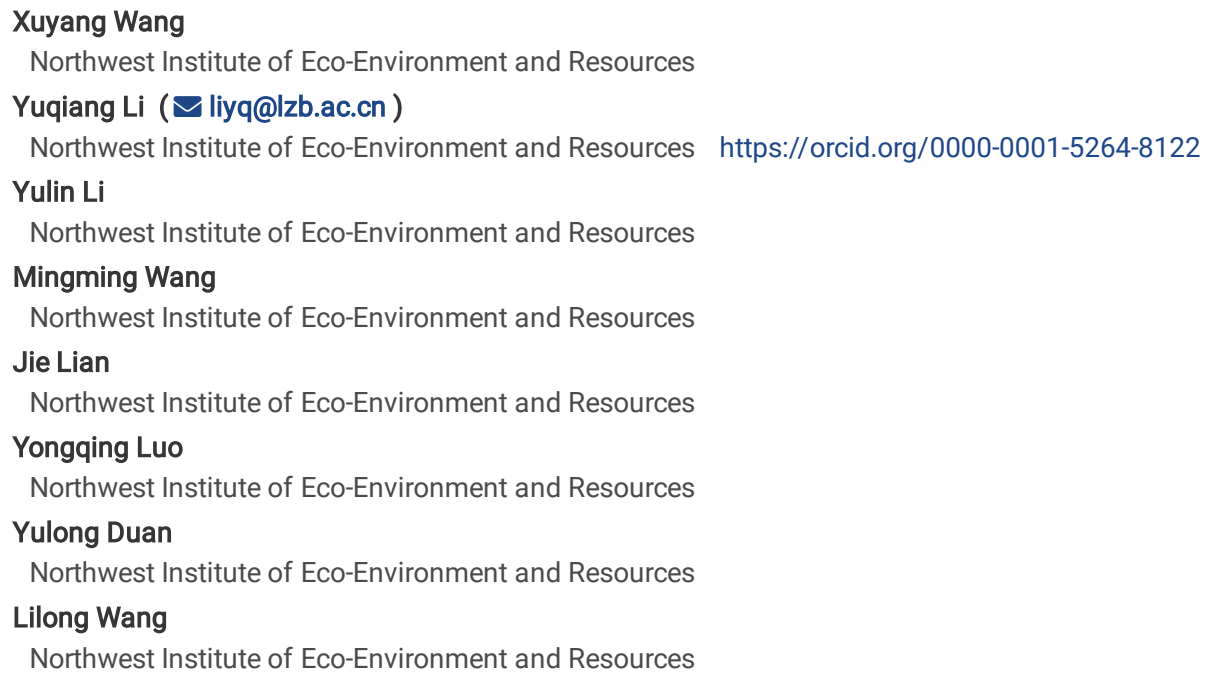




\section{Abstract}

The Qinghai-Tibet Plateau, also known as the Earth's "third pole", is sensitive to climate change due to its extensive areas at high elevation, which are presently dominated by snow and ice. Based on daily maximum and minimum surface air temperature and precipitation records at 94 meteorological stations throughout the Qinghai-Tibet Plateau, the spatial and temporal variation of 16 temperature and 11 precipitation extremal indices were investigated during 1960 to 2016. The warmth indices, including the numbers of warm days, warm nights, summer days, and tropical nights showed significantly increasing trends. In contrast, the cold indices, including the numbers of cool days, cool nights, ice days, and frost days significantly decreased. The number of frost day and ice days showed the fastest decrease (3.9 and 2.7 days/decade, respectively), whereas the growing season length showed the fastest growth trend ( 2.8 days/decade). The frequency and intensity of cold temperature events increased at high elevations, whereas warm temperature events showed the opposite trend. The regionally averaged monthly maximum 1-day precipitation and maximum consecutive 5-day precipitation increased by 0.17 and 0.70 mm per decade, respectively. In contrast, the number of consecutive dry days (CDD) and consecutive wet days (CWD) decreased at rates of 1.11 and 0.03 days per decade, respectively. The extreme precipitation events were more frequent in low-latitude and high-longitude regions. The strengthening Subtropical High Area (SHA) and Subtropical High Intensity (SHI), westward movement of Subtropical High Western Ridge Point (SHW) have contributed to the changes in climate extremes on the Qinghai-Tibet Plateau.

\section{Introduction}

Global warming has become an indisputable fact. According to statistics issued by the Fifth Assessment Report (AR5) of the Intergovernmental Panel on Climate Change (IPCC, 2013), the globally averaged surface temperatures increased by $0.85^{\circ} \mathrm{C}$ between 1880 and 2012 , and the total increase between the average for the $1850-1900$ period and the $2003-2012$ period was $0.78^{\circ} \mathrm{C}$ (IPCC, 2013). It is generally believed that changes in the frequency or intensity of extreme weather and climate events would have greater impacts on both human society and natural systems than changes in the mean climate variables (Patz et al., 2005; McMichael et al., 2006; IPCC 2012; Thornton et al., 2014). IPCC (2012) noted that there is a high confidence that economic losses from weather- and climate-related disasters have increased during the last 60 years and will have greater impacts on water, agriculture, and food security, which are closely linked to climate. Thus, understanding climate extremes has become more urgent than tracking changes in mean climate during global climate change.

To improve this understanding, increasing attention has focused on the changes of temperature and precipitation extremes around the world. At a global scale, it has been confirmed that a large proportion of the global land area has been increasingly affected by changes in climatic extremes during the second half of the 20th century (Frich et al., 2002). There were widespread significant changes in temperature extremes associated with warming during the 20th century, especially for indices derived from the daily minimum temperature. Simultaneously, extreme precipitation changes showed a widespread and significant increase, but the changes were much less spatially coherent than the temperature changes (Alexander et al., 2006). In addition, changes in temperature extremes differed between paired urban and non-urban sites at a global scale, whereas changes in indices of extreme precipitation showed no clear differentiation for paired urban and non-urban stations (Mishra et al., 2015).

Various regional studies pertaining to temperature and precipitation extreme indices have been conducted in different regions, including Europe (Klein Tank and Können, 2003), Central and South America (Aguilar et al., 2005; Haylock et al., 2006; Skansi et al., 2013), the Asia-Pacific region (Griffiths et al., 2005), the Arabian Peninsula (Alsarmi and Washington, 2014), Africa (New et al., 2006; Dike et al., 2020), Central and South Asia (Klein Tank et al., 2006), and Georgia (Keggenhoff et al., 2014). These results provide strong evidence that global warming is related to significant changes in temperature and precipitation extremes. Furthermore, climate models have been used to compute and analyze the values of extreme temperature and precipitation indices for historical periods and predict future changes in these extreme events at global and regional scales (Tebaldi et al., 2006; Kharin et al., 2007; Alexander and Arblaster, 2009; Russo and Sterl, 2011; Orlowsky and Seneviratne, 2012; Sillmann et al., 2013a, b). These studies indicated that the extreme warm temperatures and extreme precipitation events will increase but that the frequency of extreme cold temperatures will decrease. However, a lack of sufficient observed data to drive the climate models has led to large uncertainty in their findings, especially for regional-scale analyses in areas with complex physiographic conditions and limited field data to parameterize the models. To improve the accuracy of these models, it's therefore essential to analyze spatial and temporal trends in extreme climate events based on field observations.

In China, various regional studies pertaining to extreme temperature and precipitation indices have been conducted, and have provided strong evidence that global warming is causing significant changes in temperature and precipitation extremes. These results generally showed that extreme cold indices, including the numbers of frost days, cold days, and cold nights, have generally decreased in frequency and intensity, while the warmth indices, including the numbers of summer days, warm days, and warm nights, have generally increased, with varying magnitudes of change across China's diverse regions (Li et al., 2011; Zhen and Li, 2014; Guan et al., 2015; Zhong et al., 2017). The numbers of extreme precipitation events have decreased in northeastern, northwestern, and central China, but have increased in northern, southwestern, and southern China (Lu et al., 2014; Li et al., 2015; Sun et al., 2016). There were regional differences in the changes for all these metrics, which demonstrates the importance and feasibility of investigating the response of extreme climate events from a regional perspective (You et al., 2011).

The Qinghai-Tibet Plateau is a giant Chinese geomorphological unit, and lies at the highest elevation of any plateau in the world. It has a unique natural environment and high spatial differentiation. Due to limitation of atmospheric circulation caused by the plateau's topography, the plateau has a unique combination of hydrothermal conditions, with the climate ranging from warm and humid in the southeast to cold and dry in the northwest. The tectonic uplift of the plateau has profoundly affected the evolution of its natural environment and of adjacent areas, and climate change on the plateau is closely related to global environmental changes (Zheng, 1999). Therefore, the Qinghai-Tibet Plateau is considered to be a "driver and amplifier of global climatic change" (Pan and $\mathrm{Li}, 1996)$ and "the best natural laboratory for unified research on global change and Earth system science" (Bi, 1997). In recent years, a series of studies have been carried out on the Qinghai-Tibet Plateau, focusing on the characteristics of climate change (Li and Chi, 2014; Zhang et al., 2016; Liu et al., 2019a),

Page 2/19 
the relationships between climate change and vegetation (Xu and Liu, 2007; Zhang et al., 2010; Chen et al., 2014; Huang et al., 2016), and responses of the permafrost ecosystem to climate change (Cheng and Wu, 2007; Wang et al., 2011; Lu et al., 2017). However, the changes in extreme climate events are not clear. Regional assessments of regions with different climates and geography are needed to understand the uncertainties in how extreme events will respond to global warming.

The Expert Team on climate change detection, monitoring, and indices that has been sponsored by the World Meteorological Organization Commission for Climatology, and the Climate Variability and Predictability project has developed a set of indices (Peterson et al., 2001) that represent a common guideline for regional climate analysis. The aim of this study is to use field-measured values of these indices to provide a better understanding of recent changes in the variability, intensity, frequency and duration of climate extreme events across the Qinghai-Tibet Plateau. To do so, we analyzed temperature and precipitation extreme indices based on observational data from multiple meteorological stations in the region. We hypothesized that both temperature and precipitation extreme indices on the plateau would show significant long-term trends, and that these trends would exhibit spatial variation related to variations in the plateau's geographic characteristics, and the temporal variations are mainly associated with atmospheric circulation patterns.

\section{Data And Methods}

\subsection{Study area}

We defined the boundary of the Qinghai-Tibet Plateau based on the system for defining China's physical and geographical regions (Zheng, 1996). The plateau is located in southwestern China (Fig. 1), where it covers an area of 2,603,431 km². The elevation is generally greater than $4000 \mathrm{~m}$. The plateau is surrounded by high and extensive mountain ranges interlaced with valleys and basins. It is generally cold and dry in the northwest and warm and wet in the southeast, with the annual average temperature ranging from $-5.6^{\circ} \mathrm{C}$ to $17.6^{\circ} \mathrm{C}$ across the region, and the temperature difference between day and night ranges from $14^{\circ} \mathrm{C}$ to $17^{\circ} \mathrm{C}$. The precipitation distribution is uneven, with annual precipitation averaging more than $2000 \mathrm{~mm}$ in the southeast and approximately $17.6 \mathrm{~mm}$ in the northwest (Zhang et al., 2017). The annual average wind speed is generally greater than $3.0 \mathrm{~m} \mathrm{~s}^{-1}$ in the northwest, with more than 50 gale days (i.e., a wind speed $\geq 17 \mathrm{~m} \mathrm{~s}^{-1}$ ) annually (Li et al., 2001). The plateau's population density is low and is mainly concentrated in cities, towns, and river valleys with good natural conditions for farming, with an average regional population density of 5.0 persons per $\mathrm{km}^{2}$, but with a density in many areas less than 1.0 person per $\mathrm{km}^{2}$ (Lv and Yu, 2011).

\subsection{Data and quality control}

We obtained quality-controlled meteorological data, including daily maximum temperatures, minimum temperatures, and daily precipitation, from 94 meteorological stations distributed throughout the Qinghai-Tibet Plateau (Fig. 1). The data from 1960 to 2016 (the most recent data available) was obtained from the National Climate Center of the China Meteorological Administration (http://data.cma.cn). The quality and completeness of the dataset have been significantly improved as a result of strict quality control. To further ensure data quality, we (1) replaced all missing values (currently coded as - 99.9) into an internal format (i.e., NA, for not available), and (2) replaced all unreasonable values with NA. Unreasonable values include (a) a daily rainfall that was less than $0 \mathrm{~mm}$ and (b) a daily minimum temperature that was higher than the daily maximum temperature. In addition, we identified outliers in daily maximum and minimum temperatures, which we defined as daily values that lay outside a range defined as $n$ times the standard deviation (STD) of the value for that day. In this study, we defined that threshold as the mean plus or minus 5 STD based on the criteria used in previous studies (Rusticucci and Barrucand, 2004; Haylock et al., 2008; Croitoru and Piticar, 2013).

We used version 4 of the RHtests software developed by Wang and Feng at the Climate Research Branch of the Meteorological Service of Canada (http://etccdi.pacificclimate.org/software.shtml) to detect and adjust first-order autoregressive errors caused by shifts. The RHtests package was applied using the penalized maximal $t$ test (Wang et al., 2007) and the penalized maximal $F$ test (Wang, 2008b), which are embedded in a recursive testing algorithm that accounts empirically for an autocorrelation with a lag of -1 (if any) in the time series (Wang, 2008a).

\subsection{Index calculations}

The RClimDex software developed by Xuebin Zhang and Feng Yang from the Canadian Meteorological Service (Zhang and Yang, 2004) was used in this study to calculate the climatic extreme indices. We chose a total of 27 indices (16 temperature and 11 precipitation indices; Table 1) for analysis. Since 2005 , these indicators have been widely applied to assess changes in temperature and precipitation extremes for different regions of the world (Aguilar et al., 2005; Dos Santos et al., 2011; Croitoru and Piticar, 2013; Insaf et al., 2013; Guan et al., 2015; Croitoru et al., 2016; Filahi et al., 2016; Sun et al., 2016; Supari et al., 2017; Gbode et al., 2019). Table 1 provides a brief description of each index. Based on how the temperature indices are computed, they can be further grouped into four categories (Croitoru and Piticar, 2013; Wang et al., 2018). The absolute indices are defined based on a fixed threshold for the recorded temperature, and comprise the number of frost days (FD), summer days (SU), ice days (ID), and tropical nights (TR). The relative indices comprise the number of cool nights (TN10p), cool days (TX10p), warm nights (TN90p), and warm days (TX90p), which were identified using percentile-based thresholds (with values of 10 and $90 \%$ for the lower and upper bounds, respectively). The extremal indices comprise indices computed based on the absolute values recorded in the area without considering any threshold: the monthly maximum value of the daily maximum temperature (TXx), monthly maximum value of daily minimum temperature (TNx), monthly minimum value of the daily maximum temperature (TXn), and monthly minimum value of daily minimum temperature (TNn). The last category comprises four variability extremes: the growing season length (GSL), warm and cold spell durations (WSDI and CSDI), and diurnal temperature range (DTR). The precipitation indices comprise 1 dry index and 10 wet indices, and can be grouped into 2 percentile, 3 thresholds, 2 durations, 2 extremal values, and 2 other indices (Powell and Keim, 2015). 
Table 1

List of the temperature and precipitation indices used in this study, which were defined by the Expert Team on Climate Change Detection and Indices (http://etccdi.pacificclimate.org/list_27_indices.shtml.

\begin{tabular}{|c|c|c|c|}
\hline Index & Description & Definition & Unit \\
\hline FD & Frost days & Annual count for days when the minimum temperature $(\mathrm{TN})<0^{\circ} \mathrm{C}$ & Days \\
\hline SU & Summer days & Annual count for days when the maximum temperature $(T X)>25^{\circ} \mathrm{C}$ & Days \\
\hline ID & Ice days & Annual count for days when $\mathrm{TX}<0^{\circ} \mathrm{C}$ & Days \\
\hline TR & Tropical nights & Annual count for days when $\mathrm{TN}>20^{\circ} \mathrm{C}$ & Days \\
\hline TXX & Maximum TX & Monthly maximum value of $\mathrm{TX}$ & ${ }^{\circ} \mathrm{C}$ \\
\hline TNx & Maximum TN & Monthly maximum value of TN & ${ }^{\circ} \mathrm{C}$ \\
\hline TXn & Min TX & Monthly minimum value of $\mathrm{TX}$ & ${ }^{\circ} \mathrm{C}$ \\
\hline TNn & Min TN & Monthly minimum value of TN & ${ }^{\circ} \mathrm{C}$ \\
\hline TN10p & Cool nights & Percentage of days when $\mathrm{TN}<10$ th percentile & Days \\
\hline TX10p & Cool days & Percentage of days when $\mathrm{TX}<10$ th percentile & Days \\
\hline TN90p & Warm nights & Percentage of days when $\mathrm{TN}>90$ th percentile & Days \\
\hline TX90p & Warm days & Percentage of days when $T X>90$ th percentile & Days \\
\hline WSDI & $\begin{array}{l}\text { Warm spell duration } \\
\text { indicator }\end{array}$ & Annual count of the number of periods with at least 6 consecutive days when $T X>90$ th percentile & Days \\
\hline CSDI & $\begin{array}{l}\text { Cold spell duration } \\
\text { indicator }\end{array}$ & Annual count of the number of periods with at least 6 consecutive days when $\mathrm{TN}<10$ th percentile & Days \\
\hline GSL & Growing season length & $\begin{array}{l}\text { Annual count between first span after } 1 \text { January of at least } 6 \text { days with daily mean temperature } \\
(\mathrm{TM})>5^{\circ} \mathrm{C} \text { and first span after } 1 \text { July of } 6 \text { days with } \mathrm{TM}<5^{\circ} \mathrm{C}\end{array}$ & Days \\
\hline DTR & $\begin{array}{l}\text { Diurnal temperature } \\
\text { range }\end{array}$ & Monthly mean difference between TX and TN & ${ }^{\circ} \mathrm{C}$ \\
\hline RX1day & $\begin{array}{l}\text { Maximum 1-day } \\
\text { precipitation amount }\end{array}$ & Monthly maximum 1-day precipitation & $\mathrm{mm}$ \\
\hline Rx5day & $\begin{array}{l}\text { Maximum 5-day } \\
\text { precipitation amount }\end{array}$ & Monthly maximum consecutive 5-day precipitation & $\mathrm{mm}$ \\
\hline SDII & $\begin{array}{l}\text { Simple daily intensity } \\
\text { index }\end{array}$ & $\begin{array}{l}\text { Annual total precipitation divided by the number of wet days (defined as daily precipitation (PRCP) } \\
\geq 1.0 \mathrm{~mm} \text { ) in the year }\end{array}$ & $\mathrm{mm} /$ day \\
\hline R10mm & $\begin{array}{l}\text { Number of heavy } \\
\text { precipitation days }\end{array}$ & Annual count of days when PRCP $\geq 10 \mathrm{~mm}$ & Days \\
\hline R20mm & $\begin{array}{l}\text { Number of very heavy } \\
\text { precipitation days }\end{array}$ & Annual count of days when PRCP $\geq 20 \mathrm{~mm}$ & Days \\
\hline $\mathrm{R} 50 \mathrm{~mm}$ & $\begin{array}{l}\text { Number of days above } \\
50 \mathrm{~mm}\end{array}$ & Annual count of days when PRCP $\geq 50 \mathrm{~mm}$ & Days \\
\hline CDD & Consecutive dry days & Maximum number of consecutive days with daily rainfall $<1 \mathrm{~mm}$ & Days \\
\hline CWD & Consecutive wet days & Maximum number of consecutive days with daily rainfall $\geq 1 \mathrm{~mm}$ & Days \\
\hline R95PTOT & Very wet days & Annual total PRCP for days when daily rainfall $>$ 95th percentile & $\mathrm{mm}$ \\
\hline R99pTOT & Extremely wet days & Annual total PRCP for days when daily rainfall $>99$ th percentile & $\mathrm{mm}$ \\
\hline PRCPTOT & $\begin{array}{l}\text { Annual total wet-day } \\
\text { precipitation }\end{array}$ & Annual total PRCP in wet days (daily rainfall $\geq 1 \mathrm{~mm}$ ) & $\mathrm{mm}$ \\
\hline
\end{tabular}

\subsection{Atmospheric circulation patterns}

The monthly Arctic Oscillation (AO), North Atlantic Oscillation (NAO), Southern Oscillation Index (SOI), and Pacific Decadal Oscillation (PDO) data from 1960 to 2016 were available from the National Oceanic and Atmospheric Administration (http://www.esrl.noaa.gov/psd/data/climateindices/list/). In addition, the monthly West Pacific Subtropical High Index (WPSHI), including the Subtropical High Area (SHA) index, Subtropical High Intensity (SHI) index, Subtropical High Ridge Line (SHR) index, and Subtropical High Western Ridge Point (SHW) index, which obtained from the Climate Diagnostics and Prediction Division, National Climate Center, China Meteorological Administration (http://cmdp.ncc-cma.net/Monitoring/). SHW and SHR indicate the location and direction of Western Ridge Point and Ridge Line. When the Western Ridge Point is located further east, the SHW will increase; and when the Subtropical High Ridge Line is located further north, the SHR will increase. 
We used least-squares linear regression to calculate the slopes of the trends for the climate indices, combining with the Mann-Kendall test (Kendall, 1990) to detect significant trends for climate extreme indices; this non-parametric trend test is suitable for data that may not be normally distributed, and is less sensitive to the effects of outliers (Tabari et al., 2011). This method has been widely used to analyze time series to detect trends in meteorological and hydrological data (Viola et al., 2014; Sun et al., 2016; Supari et al., 2017; Zhong et al., 2017). We used the $Z$ statistic (the difference between a value and the mean, divided by STD) to judge the directions of the trends and their significance; $Z>0$ represents an increasing trend, whereas $Z<0$ represents a decreasing trend. When the absolute value of $Z$ is greater than or equal to $1.96,2.58$, and 3.30 , the trend is significant at $P<0.05,0.01$, and 0.001 , respectively (Hamed and Rao, 1998). We used inverse distance-weighted interpolation in version 10.3 of the ArcMap software (http://www.esri.com) to define the spatial pattern of trends in the climate indices. We used Pearson's correlation coefficient ( $r$ ) to detect significant relationships among the extremal variables and between extreme climate events and geographic characteristics (latitude, longitude, and elevation). Furthermore, to show the relationships between the climate indices and topographic factors more intuitively, we drew 4-dimensional graph by version 2016b of the MATLAB software (https://ww2.mathworks.cn/products/matlab.html).

\section{Results And Discussion}

\subsection{The abrupt change in extreme climate events}

\subsubsection{The abrupt change in extreme temperature events}

During the study period, the extreme temperature events have undergone abrupt changes on the Qinghai-Tibet Plateau (Table 2). The abrupt years of extreme temperature events were mainly concentrated in 1990 to 2000, except for the diurnal temperature range (DTR) in 1969. Again, the trends of temperature indices strengthened after the abrupt change, except for the weakening in the trend of DTR. GSL showed the largest increase (increased by 2.3 days/decade), and the corresponding length of the growing season before and after the abrupt change were 172.13 and 181.19 days/year, respectively. For the cold indices, the largest increase was 3.8 days/ decade for FD, and the corresponding values before and after the abrupt change were 201.69 and 188.72 days/year, respectively.

Table 2

Changes in the warmth indices and dates of the abrupt change in extreme temperature events from 1960 to 2016 on the Qinghai-Tibet Plateau.

\begin{tabular}{|c|c|c|c|c|c|c|c|}
\hline \multirow[t]{2}{*}{ Indices } & \multicolumn{3}{|c|}{ Before abrupt change } & \multirow[t]{2}{*}{ Abrupt year } & \multicolumn{3}{|c|}{ After abrupt change } \\
\hline & $K\left(\text { year }^{-1}\right)^{a}$ & Mean & $\mathbf{P}$ & & $K\left(\text { year }^{-1}\right)^{a}$ & Mean & $\mathbf{P}$ \\
\hline TX10p & -0.05 & 11.43 & 0.14 & 1999 & -0.05 & 7.79 & 0.46 \\
\hline TX90p & 0.05 & 12.18 & $<0.05$ & 2001 & 0.22 & 16.02 & 0.08 \\
\hline TN10p & -0.16 & 13.25 & $<0.01$ & 1987 & -0.12 & 8.85 & $<0.01$ \\
\hline TN90p & 0.07 & 10.74 & $<0.05$ & 1995 & 0.22 & 15.98 & $<0.01$ \\
\hline FD & -0.15 & 201.69 & $<0.05$ & 1995 & -0.53 & 188.72 & $<0.01$ \\
\hline SU & 0.05 & 24.66 & 0.09 & 2003 & 0.24 & 30.23 & 0.35 \\
\hline ID & -0.13 & 41.11 & 0.11 & 1998 & -0.23 & 31.40 & 0.23 \\
\hline TR & 0.01 & 1.25 & 0.07 & 2001 & 0.02 & 2.35 & 0.38 \\
\hline TXX & 0.01 & 17.82 & 0.16 & 1998 & 0.03 & 18.91 & 0.17 \\
\hline TXn & 0.02 & 5.22 & $<0.05$ & 2002 & 0.05 & 6.07 & $<0.05$ \\
\hline TNx & 0.03 & 3.23 & $<0.0001$ & 1994 & 0.05 & 4.34 & $<0.01$ \\
\hline TNn & 0.04 & -8.89 & $<0.0001$ & 1993 & 0.06 & -7.45 & $<0.0001$ \\
\hline GSL & 0.19 & 172.13 & $<0.05$ & 2000 & 0.42 & 181.19 & 0.09 \\
\hline WSDI & 0.07 & 9.10 & $<0.05$ & 1997 & 0.25 & 13.08 & 0.06 \\
\hline DTR & -0.06 & 14.99 & 0.08 & 1969 & -0.01 & 14.32 & $<0.01$ \\
\hline CSDI & -0.16 & 10.25 & $<0.01$ & 1992 & -0.16 & 7.01 & $<0.05$ \\
\hline
\end{tabular}

\subsubsection{The abrupt change in extreme precipitation events}

Table 3 shows that all of the extreme precipitation events have undergone abrupt changes during the study period. Most of the abrupt changes in precipitation indices occurred after 1990, while the abrupt changes of R10mm, CDD and PRCPTOT occurred earlier in 1985,1971 and 1982, respectively. R99pTOT increased the most after the abrupt change, by $20.1 \mathrm{~mm} /$ decade, with the corresponding values before and after the abrupt change were 23.46 and 27.98 $\mathrm{mm} /$ year, respectively. 
Table 3

Changes in the precipitation indices and dates of the abrupt change in extreme precipitation events during 1960 to 2016 on the Qinghai-Tibet Plateau.

\begin{tabular}{|c|c|c|c|c|c|c|c|}
\hline \multirow[t]{2}{*}{ Indices } & \multicolumn{3}{|c|}{ Before abrupt change } & \multirow[t]{2}{*}{ Year of abrupt change } & \multicolumn{3}{|c|}{ After abrupt change } \\
\hline & $K\left(\text { year }^{-1}\right)^{a}$ & Mean & $\mathbf{P}$ & & $K\left(\text { year }^{-1}\right)^{a}$ & Mean & $\mathbf{P}$ \\
\hline RX1day & 0.02 & 8.73 & $<0.05$ & 1992 & 0.02 & 9.17 & $<0.05$ \\
\hline RX5day & 0.07 & 36.27 & $<0.05$ & 1992 & 0.09 & 38.13 & $<0.05$ \\
\hline SDII & 0.00 & 5.64 & 0.30 & 2001 & 0.02 & 5.81 & 0.10 \\
\hline $\mathrm{R} 10 \mathrm{~mm}$ & 0.02 & 12.25 & 0.36 & 1985 & 0.01 & 12.90 & 0.59 \\
\hline R20mm & 0.01 & 2.66 & 0.15 & 2000 & 0.02 & 2.74 & 0.17 \\
\hline $\mathrm{R} 50 \mathrm{~mm}$ & 0.00 & 0.06 & 0.39 & 2006 & 0.00 & 0.08 & 0.91 \\
\hline CDD & -0.41 & 63.74 & 0.43 & 1971 & -0.06 & 59.11 & 0.28 \\
\hline CWD & 0.00 & 7.18 & 0.84 & 2004 & 0.02 & 7.06 & 0.44 \\
\hline R95pTOT & 0.10 & 82.99 & 0.26 & 2006 & 1.20 & 90.27 & 0.29 \\
\hline R99pTOT & 0.09 & 23.46 & $<0.05$ & 2011 & 2.19 & 27.98 & 0.07 \\
\hline PRCPTOT & 0.66 & 431.14 & 0.22 & 1982 & 0.68 & 447.81 & 0.15 \\
\hline
\end{tabular}

\subsection{Trends for extreme temperature events}

\subsubsection{Temporal trends of temperature extremes}

On the Qinghai-Tibet Plateau, the regionally averaged occurrence of cold indices, including the numbers of cool days (TX10p), cool nights (TN10p), ice days (ID), and frost days (FD) decreased significantly $(P<0.001)$, at rates of $0.98,1.53,2.71$, and 3.89 days per decade, respectively (Fig. 2$)$, the trend was strongest for TN10p ( $Z=-7.39)$. In contrast, the warmth indices for the numbers of warm days (TX90p), warm nights (TN90p), summer days (SU), and tropical nights (TR) increased significantly $(P<0.001)$, at rates of $1.06,1.60,1.37$, and 0.26 days per decade. TN90p showed the strongest increase $(Z=6.64)$. The cold temperature indices generally exhibited significant decreasing trends from 1960 to 2016 in the Qinghai-Tibet Plateau, whereas the warm temperature indices showed significant increasing trends. This is consistent with similar studies in Europe (Klein Tank and Können, 2003), Central and South America (Aguilar et al., 2005), and Africa (New et al., 2006; Gbode et al., 2019). The cold extremes (FD and ID) showed stronger trends (larger $Z$ values) than those for warm extremes (SU and TR), implying asymmetric changes in lower- and upper-tail extremes causing arising temperature variance, which was inconsistent with studies in Europe (Klein Tank and Können, 2003; Moberg et al., 2006) and Middle East countries (Zhang et al., 2005), but this finding was in agreement with earlier studies in the Yellow River Basin (Wang et al., 2012), the Loess Plateau (Sun et al., 2016), and northern China (Wang et al., 2018), demonstrating that warming since 1960 was caused by decreases of the cold extremes rather than increases of the warm extremes. The extremal indices for the warmest day ( TXx), warmest night (TNx), coldest day (TXn), and coldest night (TNn) showed significant warming trends, at rates of $0.29,0.38,0.25$, and $0.51^{\circ} \mathrm{C}$ per decade $(P<0.001)$, and the trend was strongest for TNn $(Z=8.35)$. Trends in the night-time indices (TN10p, TN90p, TNx, and TNn) were stronger (larger $Z$ scores) than those of their corresponding daytime indices (TX10p, TX90p, TXX and TXn), indicating that nocturnal warming contributed more than daytime warming to the overall warming process (Manton et al., 2001; Peterson et al., 2002; Griffiths et al., 2005; Klein Tank et al., 2006; Revadekar et al., 2013; Yan et al., 2014). In addition, for the variability extremes, both the average the diurnal temperature range (DTR) and the cold spell duration (CSDI) showed significant decreasing trends, at rates of $0.15^{\circ} \mathrm{C}$ per decade and 1.29 days per decade, respectively. However, the growing season length (GSL) and warm spell duration (WSDI) increased significantly, at rates of 2.79 and 1.27 days per decade. The rate of change for GSL in the Qinghai-Tibet Plateau was lower than the average value for the Yarlung Tsangpo River Basin (4.33 days/decade; Liu et al., 2019b) and Loess Plateau (3.16 days/decade; Sun et al., 2016), but larger than those in northwestern China (2.74 days/decade; Song et al., 2015), the Yangtze River Basin (0.23 days/decade; Wang et al., 2014), and the Yunnan-Guizhou Plateau (0.12 days/decade; Li et al., 2012a).

\subsubsection{Spatial trends in temperature extremes}

To provide further insights into spatial variation of the temperature extremes, we mapped the spatial patterns of the annual trends based on the slopes of the regressions at the 94 meteorological stations throughout and around the Qinghai-Tibet Plateau (Fig. 3). Cold indices (FD, ID, TX10p, TN10p and CSDI) showed decreasing trends in most areas, whereas warmth indices (SU, TR, TX90p, TN90p, and WSDI) showed increasing trends in most areas. The increasing trend for growing season length (GSL) was especially obvious. The trends in temperature extremes differed among stations (Fig. 3). From northwest to southeast, the trends in the cold indices increased initially, then decreased slightly and finally increased again. The trends in the cold indices in the high-altitude areas of the west were more obvious. The GSL increased throughout most of the Qinghai-Tibet Plateau, except for a small area in the southeast. In addition, the extreme indices (TXx, TXn, TNx, and TNn) showed increasing trends in most of the study area, with slopes ranging up to $0.15^{\circ} \mathrm{C} / \mathrm{year}$.

\subsubsection{Correlations among the temperature indices}

As shown in the correlation matrix for the relationships among the extreme-temperature indices (Table 4), there were significant correlations between many pairs of temperature indices. For the absolute indices (FD, ID, SU, TR) and relative indices (TX10p, TX90p, TN10p, TN90p), we found significant positive 
correlations between the warmth indices and between the cold indices. In contrast, each warmth index was negatively correlated with each cold index. This is consistent with the abovementioned results, in which the cold indices showed significantly decreasing trends, whereas the warmth indices showed significantly increasing trends. In addition, we found significant negative correlations between the cold absolute indices (FD and ID) and the extremal indices (TXx, TXn, TNx and TNn), but significant positive correlations between the warmth absolute indices (SU and TR) and the extremal indices. GSL and WSDI were significantly negatively correlated with FD and ID, but significantly positively correlated with SU and TR, which was consistent with previous studies (Lin et al., 2017; Wang et al., 2018).

Table 4

The correlation matrix (Pearson's I) for the relationships among the extreme-temperature indices in the Qinghai-Tibet Plateau from 1960 to 2016. Note: ** repr significance at $P<0.01$. All other values are not significant. Index names are defined in Table 1.

\begin{tabular}{|c|c|c|c|c|c|c|c|c|c|c|c|c|c|c|c|}
\hline Indices & TX10p & TX90p & TN10p & TN90p & FD & SU & ID & TR & TXX & TXn & TNx & TNn & GSL & WSDI & DTR \\
\hline TX10p & 1 & & & & & & & & & & & & & & \\
\hline TX90p & $-0.53^{\text {** }}$ & 1 & & & & & & & & & & & & & \\
\hline TN10p & $0.81^{* *}$ & $-0.58^{\star \star}$ & 1 & & & & & & & & & & & & \\
\hline TN90p & $-0.60^{* *}$ & $0.79^{\star *}$ & $-0.73^{* *}$ & 1 & & & & & & & & & & & \\
\hline FD & $0.69^{\star *}$ & $-0.70^{\star *}$ & $0.78^{* *}$ & $-0.87^{\star \star}$ & 1 & & & & & & & & & & \\
\hline SU & $-0.51^{* *}$ & $0.94^{\star *}$ & $-0.51^{\star *}$ & $0.72^{\star \star}$ & $-0.64^{\star *}$ & 1 & & & & & & & & & \\
\hline ID & $0.97^{\star *}$ & $-0.55^{\star *}$ & $0.82^{\star *}$ & $-0.64^{\star *}$ & $0.74^{\star *}$ & $-0.53^{\star *}$ & 1 & & & & & & & & \\
\hline TR & $-0.62^{* *}$ & $0.69^{* \star}$ & $-0.63^{\star *}$ & $0.75^{\star \star}$ & $-0.75^{\star \star}$ & $0.70^{* \star}$ & $-0.62^{\star \star}$ & 1 & & & & & & & \\
\hline TXX & $-0.82^{* *}$ & $0.76^{\star *}$ & $-0.77^{\star \star}$ & $0.76^{\star *}$ & $-0.84^{* \star}$ & $0.73^{\star *}$ & $-0.85^{\star \star}$ & $0.68^{\star *}$ & 1 & & & & & & \\
\hline TXn & $-0.78^{\star \star}$ & $0.71^{\star \star}$ & $-0.70^{\star \star}$ & $0.71^{\star \star}$ & $-0.81^{\star *}$ & $0.71^{\star \star}$ & $-0.82^{* *}$ & $0.69^{\star \star}$ & $0.84^{* *}$ & 1 & & & & & \\
\hline TNx & $-0.58^{* *}$ & $0.65^{\star *}$ & $-0.77^{\star \star}$ & $0.80^{\star *}$ & $-0.77^{\star \star}$ & $0.57^{\star *}$ & $-0.63^{\star \star}$ & $0.66^{\star *}$ & $0.71^{\star *}$ & $0.67^{\star *}$ & 1 & & & & \\
\hline TNn & $-0.54^{\star *}$ & $0.41^{\star \star}$ & $-0.52^{* *}$ & $0.41^{\star \star}$ & $-0.55^{\star \star}$ & $0.41^{\star *}$ & $-0.53^{\star \star}$ & $0.37^{\star \star}$ & $0.57^{\star \star}$ & $0.49^{\star \star}$ & 0.04 & 1 & & & \\
\hline GSL & $-0.52^{\star *}$ & $0.68^{* \star}$ & $-0.59^{\star \star}$ & $0.72^{\star \star}$ & $-0.84^{* \star}$ & $0.64^{\star \star}$ & $-0.59^{* *}$ & $0.56^{\star *}$ & $0.80^{\star \star}$ & $0.73^{* *}$ & $0.58^{\star \star}$ & $0.57^{\star \star}$ & 1 & & \\
\hline WSDI & $-0.45^{\star \star}$ & $0.85^{\star \star}$ & $-0.52^{\star \star}$ & $0.70^{\star \star}$ & $-0.57^{\star \star}$ & $0.84^{\star *}$ & $-0.47^{\star \star}$ & $0.62^{* *}$ & $0.66^{* *}$ & $0.59^{\star *}$ & $0.60^{\star \star}$ & $0.31^{*}$ & $0.61^{\star \star}$ & 1 & \\
\hline DTR & 0.07 & 0.02 & 0.04 & 0.07 & 0.05 & -0.01 & 0.03 & 0.06 & -0.07 & 0.04 & $0.49^{\star *}$ & $-0.82^{* *}$ & -0.17 & 0.07 & 1 \\
\hline CSDI & $0.71^{\text {** }}$ & $-0.49^{\star \star}$ & $0.87^{\star \star}$ & $-0.56^{\star \star}$ & $0.62^{\star \star}$ & $-0.43^{\star \star}$ & $0.69^{\star \star}$ & $-0.50^{\star \star}$ & $-0.67^{\star \star}$ & $-0.54^{\star \star}$ & $-0.55^{\star \star}$ & $-0.53^{\star \star}$ & $-0.49^{\star \star}$ & $-0.52^{\star \star}$ & 0.17 \\
\hline
\end{tabular}

\subsection{Trends for extreme precipitation events}

\subsubsection{Temporal trends of precipitation extremes}

The regionally averaged monthly maximum 1-day precipitation (RX1day) and maximum consecutive 5-day precipitation (RX5day) increased significantly, at rates of 0.17 and $0.70 \mathrm{~mm}$ per decade, respectively $(P<0.001$; Fig. 4). Similarly, the number of heavy precipitation days (R10mm), very heavy precipitation days (R20mm), and rainstorm days (R50mm) increased, at rates of $0.21,0.05$, and 0.01 days per decade, respectively, but the trend was only significant for R10mm ( $P<0.01)$. In contrast, the number of consecutive dry days (CDD) and consecutive wet days (CWD) decreased at rates of 1.11 and 0.03 days per decade, respectively, but the trend was only significant for CDD. In addition, the annual total precipitation for wet days (PRCPTOT), very wet days (R95PTOT), and extremely wet days (R99pTOT) increased by $6.1,2.0$, and $1.2 \mathrm{~mm}$ per decade, and the significant increase in precipitation intensity (SDII) also confirmed this trend.

Overall, the strengths of the trends for the precipitation indices were lower than those for the temperature indices. RX5day had the strongest trend during the study period $(Z=5.16)$, but PRCPTOT had the steepest slope $(6.11 \mathrm{~mm} /$ decade). The rate of change for RX5day $(0.70 \mathrm{~mm} / \mathrm{decade})$ was higher than that in the Yunnan-Guizhou plateau ( $0.03 \mathrm{~mm} /$ decade; Li et al., 2012a), northeastern China ( $0.13 \mathrm{~mm} / \mathrm{decade}$; Song et al., 2015), and at a global scale (0.55 mm/decade; Alexander et al., 2006), but lower than those in northwestern China ( $0.85 \mathrm{~mm} /$ decade) and for China as a whole (1.90 mm/decade; You et al., 2011$)$. In addition, the rate of increase of annual total precipitation (PRCPTOT) in this study $(6.11 \mathrm{~mm} /$ decade) was lower than that on a global scale (10.59 $\mathrm{mm}$ /decade; Alexander et al., 2006), but higher than those in Romania (4.14 mm/decade; Croitoru et al., 2016), northeastern China (1.65 mm/decade; Song et al., 2015), China's Loess Plateau (1.50 mm/decade; Sun et al., 2016), and China's Yangtze River (1.90 mm/decade; Wang et al., 2014), but lower than in Nigeria $(8.03 \mathrm{~mm} /$ decade; Gbode et al., 2019) and Georgia (7.9 mm/decade; Keggenhoff et al., 2014), and PRCPTOT showed a negative trend in Indonesia (-4.30 $\mathrm{mm} /$ decade; Supari et al., 2017). 
Figure 5 shows that the extreme precipitation indices showed increasing trends in most regions of the Qinghai-Tibet Plateau from 1960 to 2016 . In contrast, CDD decreased in most areas, especially in the high-elevation area of the central west, where the trend was most obvious. PRCPTOT increased in most areas, with only small areas in the southwestern and eastern edges of the plateau showing a decreasing trend. Both R95pTOT and R99pTOT showed overall increases, with the strongest trends in the northeast region and a narrow band with decreasing values running from southwest to east. The trends for remaining extreme precipitation indices showed less spatial heterogeneity.

\subsubsection{Correlation coefficients for the precipitation indices}

As shown in Table 5, we found strong positive correlations between the annual total precipitation (PRCPTOT, daily precipitation $>1 \mathrm{~mm}$ ) and all of the extreme precipitation indices except R50mm (not significant) and the consecutive dry days (CDD, $r=-0.27, P<0.05$ ). The correlation coefficients were greater than 0.50 for the relationships between the PRCPTOT and several of the extreme precipitation indices: the monthly maximum 1-day precipitation (RX1day), maximum consecutive 5-day precipitation (RX5day), simple daily intensity index (SDII), heavy precipitation (R10mm), very heavy precipitation (R20mm), and annual precipitation on very wet days (R95pTOT). There were significant positive correlations among most of the extreme precipitation indices, but negative correlations between consecutive dry days (CDD) and the precipitation indices. This confirmed our previous research results for China as a whole (Wang et al., 2020).

Table 5

The correlation matrix (Pearson's r) for the relationships among the extreme- precipitation indices in the Qinghai-Tibet Plateau from 1960 to

\begin{tabular}{|c|c|c|c|c|c|c|c|c|c|c|c|}
\hline Indices & RX1day & RX5day & SDII & $\mathrm{R} 10 \mathrm{~mm}$ & $\mathrm{R} 20 \mathrm{~mm}$ & $\mathrm{R} 50 \mathrm{~mm}$ & CDD & CWD & R95рT0T & R99pTOT & PRCPTOT \\
\hline RX1day & 1 & & & & & & & & & & \\
\hline RX5day & $0.99^{\star *}$ & 1 & & & & & & & & & \\
\hline SDII & $0.56^{\star *}$ & $0.56^{* *}$ & 1 & & & & & & & & \\
\hline $\mathrm{R} 10 \mathrm{~mm}$ & $0.52^{\star \star}$ & $0.53^{\star \star}$ & $0.62^{\star \star}$ & 1 & & & & & & & \\
\hline R20mm & $0.62^{\star \star}$ & $0.62^{\star \star}$ & $0.64^{\star \star}$ & $0.69^{\text {** }}$ & 1 & & & & & & \\
\hline $\mathrm{R} 50 \mathrm{~mm}$ & $0.51^{\star *}$ & $0.53^{* \star}$ & $0.48^{\star *}$ & 0.11 & $0.37^{\star \star}$ & 1 & & & & & \\
\hline CDD & $-0.42^{\star *}$ & $-0.41^{\star *}$ & -0.04 & -0.14 & -0.08 & -0.04 & 1 & & & & \\
\hline CWD & -0.09 & -0.09 & 0.07 & $0.29^{\star}$ & 0.18 & -0.10 & 0.08 & 1 & & & \\
\hline R95рт0T & $0.71^{\star \star}$ & $0.72^{\star \star}$ & $0.78^{\star \star}$ & $0.71^{\text {** }}$ & $0.90^{\text {** }}$ & $0.50^{\star \star}$ & -0.13 & 0.10 & 1 & & \\
\hline R99pTOT & $0.74^{\star *}$ & $0.75^{\star *}$ & $0.65^{\star *}$ & $0.43^{* *}$ & $0.68^{* *}$ & $0.59^{* *}$ & -0.04 & -0.04 & $0.83^{\star *}$ & 1 & \\
\hline PRCPTOT & $0.633^{\star \star}$ & $0.626^{* *}$ & $0.544^{\star *}$ & $0.934^{\star *}$ & $0.71^{\text {** }}$ & 0.16 & $-0.27^{*}$ & $0.35^{\star *}$ & $0.72^{* *}$ & $0.47^{\star \star}$ & 1 \\
\hline
\end{tabular}

\subsection{Relationships between temperature extremes and latitude, longitude and altitude}

We observed large spatial variation in the temperature extremes. To clarify the reasons for the different trends in different regions, we analyzed the correlations between extreme temperature events and the latitude, longitude, and elevation of each meteorological station (Table 6). 
Table 6

Correlations (Pearson's r) between the temperature extremes from 1960 to 2016 and the latitude, longitude, and elevation of the measurement sites in the Qinghai-Tibet Plateau. Index names are defined in Table 1.

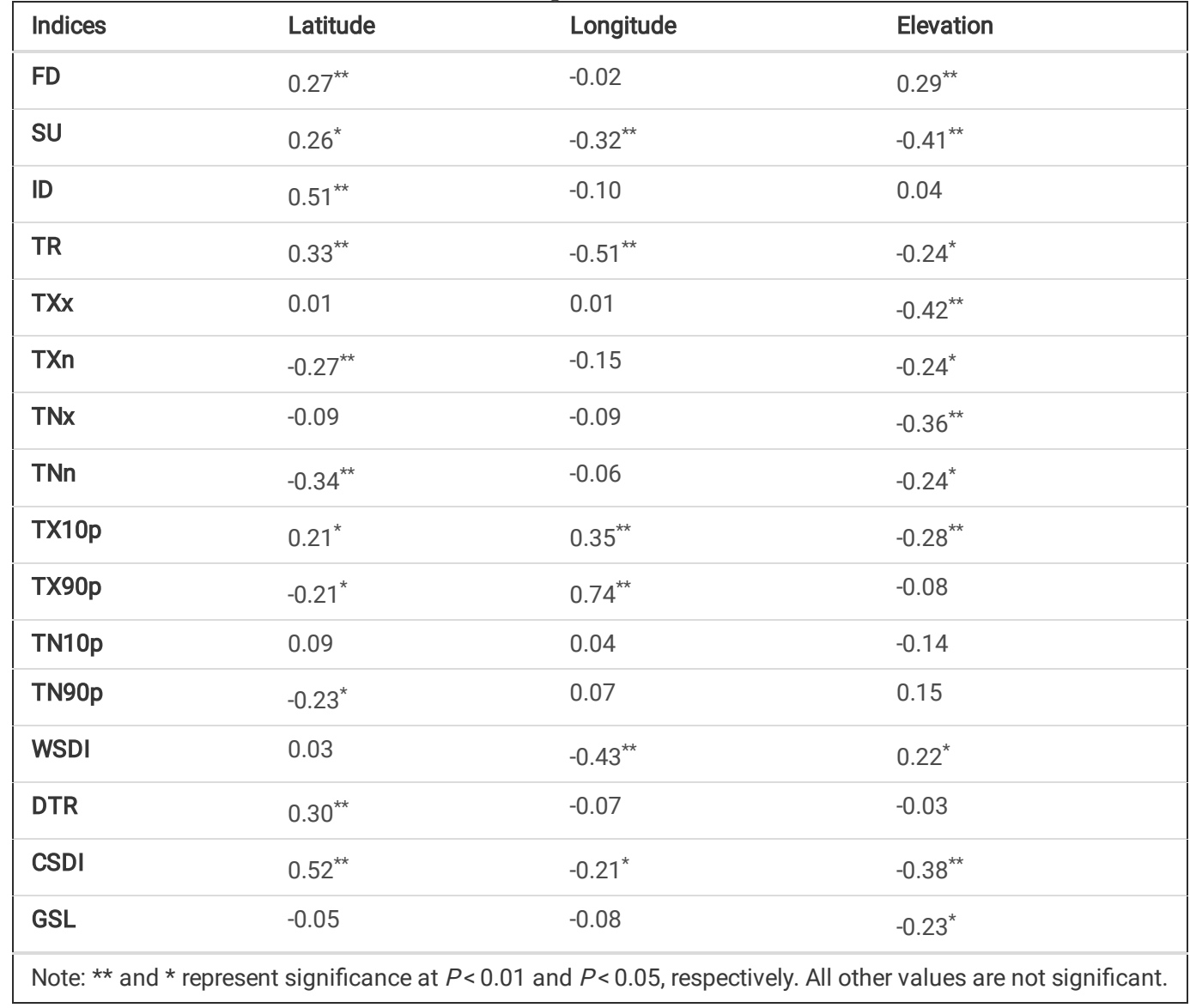

Latitude affects the solar incidence angle, and thereby influences the distribution of energy over the Earth's surface. In general, higher latitude areas have a lower solar incidence angle, so they receive less heat, leading to colder temperatures. In contrast, the temperatures are higher at lower latitudes because more solar radiation is intercepted. Warming trends tend to be more evident at high latitudes in the northern hemisphere (Serreze et al., 2000). In the present study, the absolute indices (FD, ID, SU, TR) showed significant positive correlations with latitude, whereas the extremal indices for the warmest day (TXn, TNn) showed negative correlations with latitude, indicating that the magnitude of daily extreme temperature events would decrease with increasing latitude. The relative warmth indices (TX10p and TN10p) showed positive correlations with latitude, although the correlation was only significant for TX10p, whereas the relative cold indices (TX90p and TN90p) both showed significant negative correlations. This indicates that the warming trend became more significant with increasing latitude, which was consistent with previous research in the Yangtze River Basin (Guan et al., 2015) and the Hengduan Mountains of China (Li et al., 2012a,b). Furthermore, two of the variability extremes (CSDI and DTR) showed significant positive correlations with latitude, whereas GSL was not significantly correlated with latitude.

Longitude affects regional climate change by influencing the transport of water and energy between coastal regions ((including southwestern areas such as the Indian Ocean and northern areas such as the Arctic Ocean) and China's inland areas (Zhong et al., 2017). In the present study, two of the absolute indices (SU and TR) and two of the variability extremes (WSDI and CSDI) showed significant negative correlations with longitude, whereas two of the relative warmth indices (TX10p and TX90p) were significantly positively correlated with longitude, indicating that the occurrence of daytime extreme temperature events would increase with increasing longitude.

Elevation determines the vertical distribution of energy and water, and thereby influences regional climate change. In the present study, only one of the cold indices (FD) showed a significant $(P<0.01)$ positive correlation with elevation, whereas both warmth indices (SU and TR) showed significant negative correlations with elevation $(P<0.05)$. This indicated that the frequency and intensity of cold temperature events increased at high elevations, whereas warm temperature events showed the opposite trend. The extremal indices for the warmest day (TXX), warmest night (TNx), coldest day (TXn), and coldest night $(\mathrm{TNn})$ all showed significant negative correlations with elevation $(P<0.05)$, indicating that the occurrences of daily extreme temperature events would decrease with increasing elevation. In addition, the wet spell duration (WSDI) increased significantly with increasing elevation, whereas the cold spell duration (CSDI) and growing season length (GSL) both decreased with increasing elevation.

\subsection{Relationships between precipitation extremes and latitude, longitude and altitude}

Similarly, we analyzed the correlations between extreme precipitation events and latitude, longitude, and elevation (Table 7). All of the precipitation indices showed significant negative correlations with latitude, except for a significant positive correlation for the number of consecutive dry days (CDD). This indicates that the extreme precipitation events were more frequent at low latitudes, probably due mainly to the greater precipitation due to the proximity of low- 
latitude areas to moist coastal areas in eastern China and orographic effects created by the southern mountains. Longitude had the opposite effect on extreme precipitation events, with all of the precipitation indices showing significant positive correlations with longitude, except for CDD (with a significant negative correlation) and R50mm showing a nonsignificant correlation. This may be because the areas with a higher longitude are closer to the coast, where the moisture supply is much greater than in dry regions farther to the west. This also confirmed our previous research results across China (Wang et al., 2020). We found no significant correlations between the precipitation indexes and elevation, possibly because of the negative interaction between elevation and proximity to moisture sources.

Table 7

Correlations (Pearson's r) between precipitation extremes from 1960 to 2016 and the latitude, longitude, and elevation of the measurement sites in the QinghaiTibet Plateau. Index names are defined in Table 1.

\begin{tabular}{|llll|}
\hline Indices & Latitude & Longitude & Elevation \\
\hline RX1day & $-0.58^{* *}$ & $0.54^{* *}$ & 0.03 \\
\hline R99pTOT & $-0.58^{* *}$ & $0.49^{* *}$ & 0.04 \\
\hline R95pTOT & $-0.58^{* *}$ & $0.53^{* *}$ & 0.004 \\
\hline CWD & $-0.73^{* *}$ & $0.40^{* *}$ & 0.14 \\
\hline CDD & $0.44^{* *}$ & $-0.63^{* *}$ & -0.10 \\
\hline PRCPTOT & $-0.59^{* *}$ & $0.55^{* *}$ & 0.01 \\
\hline RX5day & $-0.58^{* *}$ & $0.53^{* *}$ & 0.03 \\
\hline SDII & $-0.62^{* *}$ & $0.39^{* *}$ & 0.02 \\
\hline R20mm & $-0.53^{* *}$ & $0.36^{* *}$ & -0.09 \\
\hline R50mm & $-0.27^{* *}$ & 0.06 & -0.05 \\
\hline R10mm & $-0.59^{* *}$ & $0.52^{* *}$ & -0.04 \\
\hline Note: ** represents significance at $P<0.01$. All other values are not significant. \\
\hline
\end{tabular}

3.6 Relationships between temperature extremes and atmospheric circulation patterns

Table 8 shows the correlations between temperature extremes and atmospheric circulation patterns. The Subtropical High Intensity (SHI) and Subtropical High Area (SHA) showed significant positive correlations with warmth indices (TX90p, TN90p, SU, TR, WSDI), extremal indices (TXx, TXn, TNx, TNn) and the growing season length, whereas SHI and SHA showed significant negative correlations with cold indices (TX10p, TN10p, FD, ID, CSDI). The correlations between the Subtropical High Western Ridge Point (SHW) and temperature extremes showed the opposite responses. When the SHW moves northward, the cold events were likely to increase significantly, whereas the warming events were likely to decrease significantly on the Qinghai-Tibet Plateau. As an important component of East Asian monsoon, the West Pacific Subtropical High (WPSH) has a significant impact on temperature and precipitation in China (Zhao and Wang, 2017). Zhong et al. (2017) found that the Northern Hemisphere Subtropical High area and intensity indices showed positive correlations with the warm indices and extreme indices, while showed the reverse relationship with the cold indices. Sun et al. (2016) also found that the SHI strongly influences warm/cold extremes and contributes significantly to climate changes in the Loess Plateau. 
Table 8

Correlations (Pearson's $r$ ) between temperature extremes and atmospheric circulation

\begin{tabular}{|c|c|c|c|c|c|c|c|c|}
\hline Indices & SHA & SHI & SHR & SHW & AO & NAO & PDO & sol \\
\hline TX10p & $-0.546^{* *}$ & $-0.518^{\star *}$ & 0.080 & $0.581^{\star *}$ & 0.112 & 0.148 & -0.107 & -0.027 \\
\hline TX90p & $0.554^{\star *}$ & $0.542^{* \star}$ & 0.062 & $-0.544^{\star *}$ & 0.115 & -0.063 & -0.072 & 0.043 \\
\hline TN10p & $-0.626^{* *}$ & $-0.587^{\star \star}$ & 0.038 & $0.693^{\star *}$ & -0.167 & -0.052 & -0.211 & 0.035 \\
\hline TN90p & $0.672^{\star *}$ & $0.653^{* *}$ & 0.008 & $-0.683^{* *}$ & 0.021 & -0.178 & 0.024 & 0.098 \\
\hline FD & $-0.664^{* *}$ & $-0.656^{\star *}$ & -0.008 & $0.651^{\star *}$ & -0.033 & 0.134 & -0.020 & -0.217 \\
\hline SU & $0.504^{\star *}$ & $0.500^{\star \star}$ & 0.134 & $-0.478^{\star \star}$ & 0.081 & -0.066 & -0.106 & 0.079 \\
\hline ID & $-0.619^{* *}$ & $-0.598^{\star \star}$ & 0.078 & $0.643^{\star \star}$ & 0.076 & 0.120 & -0.177 & 0.019 \\
\hline TR & $0.550^{* *}$ & $0.558^{\star \star}$ & -0.008 & $-0.516^{\star *}$ & 0.000 & -0.220 & -0.094 & 0.175 \\
\hline TXx & $0.591^{* *}$ & $0.577^{\star \star}$ & 0.116 & $-0.601^{* \star}$ & 0.003 & -0.065 & 0.041 & 0.090 \\
\hline TXn & $0.607^{\star *}$ & $0.605^{\star *}$ & 0.036 & $-0.570^{\star \star}$ & -0.020 & -0.187 & -0.002 & 0.138 \\
\hline TNx & $0.590^{\star *}$ & $0.577^{\star \star}$ & 0.067 & $-0.589^{* \star}$ & 0.234 & -0.003 & 0.120 & 0.096 \\
\hline TNn & $0.416^{* *}$ & $0.390^{\star \star}$ & -0.133 & $-0.463^{\star *}$ & -0.125 & -0.045 & 0.107 & -0.059 \\
\hline GSL & $0.575^{\star *}$ & $0.568^{\star \star}$ & 0.099 & $-0.570^{\star \star}$ & 0.101 & 0.008 & -0.025 & 0.156 \\
\hline WSDI & $0.592^{\star *}$ & $0.604^{\star *}$ & 0.053 & $-0.560^{\star *}$ & 0.032 & -0.067 & 0.111 & -0.014 \\
\hline DTR & -0.021 & 0.001 & 0.136 & 0.084 & 0.180 & -0.020 & -0.035 & 0.116 \\
\hline CSDI & $-0.516^{* *}$ & $-0.482^{\star *}$ & 0.004 & $0.608^{* *}$ & -0.093 & -0.077 & -0.221 & 0.087 \\
\hline
\end{tabular}

\subsection{Relationships between precipitation extremes and atmospheric circulation patterns}

As shown in Table 9, SHI and SHA had positive correlations with all the extreme precipitation indices, except for the reverse relationship with CDD, indicating that the frequency and intensity of extreme precipitation events increased with increasing intensity and area of the West Pacific Subtropical High. On the contrary, SHW had negative correlations with all the extreme precipitation indices, except for positive correlations with CWD and CDD. This indicates that when the SHW moves westward, extreme precipitation events are likely to increase significantly, whereas the extreme precipitation events would decrease if SHW moves eastward.

Table 9

Correlations (Pearson's $r$ ) between precipitation extremes and atmospheric circulation patterns

\begin{tabular}{|c|c|c|c|c|c|c|c|c|}
\hline Indices & SHA & SHI & SHR & SHW & $\mathrm{AO}$ & NAO & PDO & sol \\
\hline RX1day & $0.534^{\star *}$ & $0.517^{\star \star}$ & 0.131 & $-0.565^{\star *}$ & 0.153 & -0.013 & 0.065 & 0.218 \\
\hline RX5day & $0.532^{* *}$ & $0.513^{\star *}$ & 0.107 & $-0.561^{\star \star}$ & 0.163 & 0.001 & 0.081 & 0.220 \\
\hline SDII & $0.524^{\star *}$ & $0.531^{\star \star}$ & 0.088 & $-0.455^{\star \star}$ & -0.093 & -0.116 & 0.090 & 0.248 \\
\hline R10mm & $0.431^{\star \star}$ & $0.445^{\star \star}$ & 0.172 & $-0.395^{\star *}$ & -0.045 & -0.124 & 0.054 & 0.256 \\
\hline $\mathrm{R} 20 \mathrm{~mm}$ & $0.339^{*}$ & $0.358^{* *}$ & 0.132 & $-0.300^{\star}$ & -0.104 & -0.102 & 0.086 & 0.183 \\
\hline R50mm & $0.327^{\star}$ & $0.315^{*}$ & -0.006 & $-0.321^{*}$ & -0.018 & -0.121 & 0.144 & 0.029 \\
\hline CDD & $-0.280^{*}$ & -0.216 & 0.150 & $0.362^{\star \star}$ & $-0.281^{*}$ & -0.064 & -0.199 & 0.066 \\
\hline CWD & 0.010 & 0.026 & -0.005 & 0.001 & -0.212 & -0.092 & 0.042 & 0.117 \\
\hline R95pTOT & $0.416^{* *}$ & $0.440^{* *}$ & 0.190 & $-0.349^{\star \star}$ & -0.023 & -0.088 & 0.034 & $0.283^{*}$ \\
\hline R99pTOT & $0.422^{* *}$ & $0.454^{\star *}$ & 0.133 & $-0.345^{\star \star}$ & -0.083 & -0.153 & 0.022 & 0.255 \\
\hline PRCPTOT & $0.408^{\star *}$ & $0.419^{\star \star}$ & 0.148 & $-0.397^{\star \star}$ & -0.039 & -0.195 & 0.021 & $0.317^{\star}$ \\
\hline
\end{tabular}




\section{Conclusions}

We used 16 extreme temperature and 11 extreme precipitation indices to quantify the changes in climate extremes and their relationship with several atmospheric circulation patterns on China's Qinghai-Tibetan Plateau. The warmth indices, including warm days and nights, summer days, and tropical nights, showed significantly increasing trends. Over the same period, the cold indices, including cool days and nights, ice days, and frost days decreased significantly. Furthermore, the extremal daily indices, including the warmest day, warmest night, coldest day, and coldest night showed significant increasing trends during the same period. The relative warmth indices showed positive correlations with latitude, whereas the relative cold indices showed negative correlations, indicating that the warming trend became more significant with increasing latitude. In addition, the frequency and intensity of cold temperature events increased at high elevations, whereas warm temperature events showed the opposite trend. The total annual precipitation and extreme precipitation events showed increasing trends from 1960 to 2016, except for the numbers of consecutive dry and wet days. The extreme precipitation events were more frequent at lower latitudes and higher longitudes, but there was no relationship with elevation. These results confirmed our hypotheses that monitoring of temperatures and precipitation on the Qinghai-Tibet Plateau would show trends consistent with global warming, and would reveal significant spatial variation in these trends. The West Pacific Subtropical High Index (WPSHI), such as the Subtropical High Area (SHA), Subtropical High Intensity (SHI), and Subtropical High Western Ridge Point (SHW) strongly influence temperature and precipitation extremes. The strengthening SHA and SHI, Westward movement of SHW have contributed to the changes in climate extremes on the Qinghai-Tibet Plateau.

Despite the large number of monitoring stations, coverage of the study area was not optimal, particularly for the large gap in coverage in the northwestern plateau. Adding stations in this region or finding ways to use satellite data to monitor these remote areas would mitigate this problem. Our results suggest that the increasing number and severity of extreme climatic events will pose a growing risk to crops, and thus to China's food security, but may also lead to adverse vegetation changes and increased soil erosion on the plateau.

\section{Declarations}

\section{Funding Statement}

This research was supported by the National Key R and D Program of China (2017YFA0604803), the National Natural Science Foundation of China (grants 32001214 and 31971466), and the Strategic Priority Research Program of the Chinese Academy of Sciences (XDA23060404).

Author contributions Xuyang Wang: writing the initial draft; Yuqiang Li and Yulin Li: supervision, mentorship; Mingming Wang, Jie Lian, and Yongqing, Luo: application of the techniques, data analysis; Yulong Duan and Lilong Wang: reviewing and editing.

Code availability Not applicable.

Data availability The raw data supporting the conclusions of this article will be made available by the authors, without undue reservation.

\section{Declarations}

Ethics approval The authors confirm that this article is original research and has not been published or presented previously in any journal or conference in any language (in whole or in part).

Conflicts of interest The authors declare that they have no conflict of interest.

\section{References}

Aguilar, E., Peterson, T.C., Ramírez Obando P., Frutos R., Retana J.A., Solera M., Soley J., González-García, I., Araujo, R.M., Rosa Santos, A., Valle, V.E., and Brunet, M. (2005). Changes in precipitation and temperature extremes in Central America and northern South America, 1961-2003. Journal of Geophysical Research, 110, D23107, DOI: 10.1029/2005JD006119.

Alexander, L.V., and Arblaster, J.M. (2009). Assessing trends in observed and modeled climate extremes over Australia in relation to future projections. International Journal of Climatology, 29, 417-435, DOI: 10.1002/joc.1730.

Alexander, L.V., Zhang, X., Peterson, T.C., Caesar, J., Gleason, B., Klein Tank, A.M.G., Haylock, M., Collins, D., Trewin, B., Rahimzadeh, F., Tagipour, A., Rupa Kumar, K., Revadekar, J., Griffiths, G., Vincent, L., Stephenson, D.B., Burn, J., Aguilar, E., Brunet, M., Taylor, M., New, M., Zhai, P., Rusticucci, M., and VazquezAguirre, J.L. (2006). Global observed changes in daily climate extremes of temperature and precipitation. Journal of Geophysical Research: Atmospheres, 111, D05109, DOI: 10.1029/2005JD006290.

Alsarmi, S.H., and Washington, R. (2014). Changes in climate extremes in the Arabian Peninsula: analysis of daily data. International Journal of Climatology, 34(5), 1329-1345. DOI: 10.1002/joc.3772.

Bi S. (1997). A best laboratory of the universal research for the Earth's global change and Earth system science-the Qinghai-Tibet Plateau. System Engineering Theory and Practice, (5), 72-77 (In Chinese).

Chen, B., Zhang, X., Tao, J., Wu, J., Wang, J., Shi, P., Zhang, Y., and Yu, C. (2014). The impact of climate change and anthropogenic activities on alpine grassland over the Qinghai-Tibet Plateau. Agricultural and Forest Meteorology, 189-190, 11-18, DOI: 10.1016/j.agrformet.2014.01.002. 
Cheng, G., and Wu, T. (2007). Responses of permafrost to climate change and their environmental significance, Qinghai-Tibet Plateau. Journal of Geophysical Research, 112, F02S03, DOI: 10.1029/2006JF000631.

Croitoru, A.E., and Piticar, A. (2013). Changes in daily extreme temperatures in the extra-Carpathians regions of Romania. International Journal of Climatology, 33, 1987-2001, DOI: 10.1002/joc.3567.

Croitoru, A.E., Piticar, A., and Buradac, D.C. (2016). Changes in precipitation extremes in Romania. Quaternary International, 415, 325-335, D0I: 10.1016/j.quaint.2015.07.028.

Dike, V.N., Lin, Z., and Ibe, C.C. (2020). Intensification of summer rainfall extremes over Nigeria during recent decades. Atmosphere, 11(10), 1084, DOI: $10.3390 /$ atmos 11101084 .

Dos Santos, C.A.C., Neale, C.M.U., Rao, T.V.R., and da Silva, B.B. (2011). Trends in indices for extremes in daily temperature and precipitation over Utah, USA. International Journal of Climatology, 31, 1813-1822, DOI: 10.1002/joc.2205.

Filahi, S., Tanarhte, M., Mouhir, L., El Morhit, M., and Tramblay, Y. (2016). Trends in indices of daily temperature and precipitations extremes in Morocco. Theoretical and Applied Climatology, 124, 959-972, DOI 10.1007/s00704-015-1472-4.

Frich, P., Alexander, L.V., Della-Marta, P., Gleason, B., Haylock, M., Klein Tank, A.M.G., and Peterson, T. (2002). Observed coherent changes in climatic extremes during the second half of the twentieth century. Climate Research, 19, 193-212, DOI: 10.3354/cr019193.

Gbode, I.E., Adeyeri, O.E., Menang, K.P., Intsiful, J.D.K., Ajayi, V.O., Omotosho, J.A., and Akinsanola, A.A. (2019). Observed changes in climate extremes in Nigeria. Meteorological Applications, 26(4), 642-654, DOI: 10.1002/met.1791.

Griffiths, G.M., Chambers, L.E., Haylock, M.R., Manton, M.J., Nicholls, N., Baek, H.J., Choi, Y., Della-Marta, P.M., Gosai, A., Iga, N., Lata, R., Laurent, V., Maitrepierre, L., Nakamigawa, H., Ouprasitwong, N., Solofa, D., Tahani, L., Thuy, D.T., Tibig, L., Trewin, B., Vediapan, K., and Zhai, P. (2005). Change in mean temperature as a predictor of extreme temperature change in the Asia-Pacific region. International Journal of Climatology, 25, 1301-1330. D0I: 10.1002/joc.1194.

Guan, Y., Zhang, X., Zheng, F., and Wang, B. (2015). Trends and variability of daily temperature extremes during 1960-2012 in the Yangtze River Basin, China. Global and Planetary Change, 124, 79-94, DOI: 10.1016/j.gloplacha.2014.11.008.

Hamed, K.H., and Rao, A.R. (1998). A modified Mann-Kendall trend test for autocorrelated data. Journal of Hydrology, 204, 182-196, DOI: 10.1016/S00221694(97)00125-X.

Haylock, M.R., Hofstra, N., Klein Tank, A.M.G., Klok, E.J., Jones, P.D., and New, M. (2008). A European daily high-resolution gridded data set of surface temperature and precipitation for 1950-2006. Journal of Geophysical Research, 113, D20119, DOI: 10.1029/2008JD010201.

Haylock, M.R., Peterson, T.C., Alves, L.M., Ambrizzi, T., Anunciação, Y.M.T., Baez, J., Barros, V.R., Berlato, M.A., Bidegain, M., Coronel, G., Corradi, V., Garcia, V.J., Grimm, A.M., Karoly, D., Marengo, J.A., Marino, M.B., Moncunill, D.F., Nechet, D., Quintana, J., Rebello, E., Rusticucci, M., Santos, J.L., Trebejo, I., and Vincentu, L.A. (2006). Trends in total and extreme South American rainfall 1960-2000 and links with sea surface temperature. Journal of Climate, 19, 1490-1512, DOI: 10.1175/JCLI3695.1.

Huang, K., Zhang, Y., Zhu, J., Liu, Y., Zu, J., and Zhang, J. (2016). The influences of climate change and human activities on vegetation dynamics in the Qinghai-Tibet Plateau. Remote Sensing, 8(10), 876, DOI: 10.3390/rs8100876.

Insaf, T.Z., Lin, S., and Sheridan, S.C. (2013). Climate trends in indices for temperature and precipitation across New York State, 1948-2008. Air Quality, Atmosphere \& Health, 6, 247-257, DOI: 10.1007/s11869-011-0168-x.

IPCC, (2012). Managing the risks of extreme events and disasters to advance climate change adaptation. In: Field, C.B., Barros, V., Stocker, T.F., Qin, D. (eds) A special report of working groups I and II of the intergovernmental panel on climate change. Cambridge University Press, Cambridge.

IPCC, (2013). Summary for Policymakers. In: Stocker, T.F., Qin, D., Plattner, G.-K., Tignor, M., Allen, S.K., Boschung, J., Nauels, A., Xia, Y., Bex, V., Midgley, P.M. (Eds.), Climate Change 2013: The Physical Science Basis. Contribution of Working Group I to the Fifth Assessment Report of the Intergovernmental Panel on Climate Change. Cambridge University Press, Cambridge, United Kingdom.

Keggenhoff, I., Elizbarashvili, M., Amiri-Farahani, A., and King, L. (2014). Trends in daily temperature and precipitation extremes over Georgia, $1971-2010$. Weather and Climate Extremes, 4, 75-85. DOI: 10.1016/j.wace.2014.05.001.

Kendall, M.G. (1990). Rank correlation methods. British Journal of Psychology, 25, 86-91, DOI: 10.1111/j.2044-8295.1934.tb00727.x.

Kharin, V., Zwiers, F.W., Zhang, X., and Hegerl, G.C. (2007). Changes in temperature and precipitation extremes in the IPCC ensemble of global coupled model simulations. Journal of Climate, 20, 1419-1444, DOI: 10.1175/JCLI4066.1.

Klein Tank, A.M.G., and Können, G.P. (2003). Trends in indices of daily temperature and precipitation extremes in Europe, 1946-99. Journal of Climate, 16, 3665-3680, DOI: 10.1175/1520-0442(2003)0162.0.CO;2 
Klein Tank, A.M.G., Peterson, T.C., Quadir, D.A., Dorji, S., Zou, X., Tang, H., Santhosh, K., Joshi, U.R., Jaswal, A.K., Kolli, R.K., Sikder, A.B., Deshpande, N.R., Revadekar, J.V., Yeleuova, K., Vandasheva, S., Faleyeva, M., Gomboluudev, P., Budhathoki, K.P., Hussain, A., Afzaal, M., Chandrapala, L., Anvar, H., Amanmurad, D., Asanova, V.S., Jones, P.D., New, M.G., and Spektorman, T. (2006). Changes in daily temperature and precipitation extremes in central and south Asia. Journal of Geophysical Research, 111, D16105, DOI: 10.1029/2005JD006316.

Li, R., and Chi, X. (2014). Thermal comfort and tourism climate changes in the Qinghai-Tibet Plateau in the last 50 years. Theoretical and Applied Climatology, 117(3-4), 613-624, DOI: 10.1007/s00704-013-1027-5.

Li, S., Dong, Y.X., and Dong, G.R. (2001). Sandy desertification problem and sustainable development in Qinghai-Tibet Plateau. China Tibetology Publishing House, Beijing (in Chinese).

Li, Y., He, D., Hu, J., and Cao, J. (2015). Variability of extreme precipitation over Yunnan Province, China 1960-2012. International Journal of Climatology, 35, 245-258, DOI: 10.1002/joc.3977.

Li, Z., He, Y., Wang, P., Theakstone, W.H., An, W., Wang, X., Lu, A., Zhang, W., and Cao, W. (2012a). Changes of daily climate extremes in southwestern China during 1961-2008. Global and Planetary Change, 80, 255-272, DOI: 10.1016/j.gloplacha.2011.06.008.

Li, Z., Zheng, F., Liu, W., and Jiang, D. (2012b). Spatially downscaling GCMs outputs to project changes in extreme precipitation and temperature events on the Loess Plateau of China during the 21st Century. Global and Planetary Change, 82, 65-73, DOI: DOI: 10.1016/j.gloplacha.2011.11.008.

Li, Z.X., He, Y.Q., Wang, C.F., Wang, X.F., Xin, H.J., Zhang, W., and Cao, W.H. (2011). Spatial and temporal trends of temperature and precipitation during 19602008 at the Hengduan Mountains, China. Quaternary International, 236, 127-142. DOI: 10.1016/j.quaint.2010.05.017.

Lin, P., He, Z., Du, J., Chen, L., Zhu, X., and Li, J. (2017). Recent changes in daily climate extremes in an arid mountain region, a case study in northwestern China's Qilian Mountains. Scientific Reports, 7(1), 2245, DOI: 10.1038/s41598-017-02345-4.

Liu, J., Shangguan, D., Liu, S., Ding, Y., and Wang, X. (2019a). Evaluation and comparison of CHIRPS and MSWEP daily-precipitation products in the QinghaiTibet plateau during the period of 1981-2015. Atmospheric Research, 230, 104634, DOI: 10.1016/j.atmosres.2019.104634.

Liu, C., Li, Y., Ji, X., Luo, X. and Zhu, M. (2019b). Observed changes in temperature and precipitation extremes over the Yarlung Tsangpo River Basin during 1970-2017. Atmosphere, 10, 815, DOI: 10.3390/atmos10120815.

Lu, H., Chen S., Guo, Y., He, H., and Xu, S. (2014). Spatio-temporal variation characteristics of extremely heavy precipitation frequency over South China in the last 50 years. Journal of Tropical Meteorology, 20, 279-288, DOI: 10.16555/j.1006-8775.2014.03.010.

Lu, Q., Zhao, D., and Wu, S. (2017). Simulated responses of permafrost distribution to climate change on the Qinghai-Tibet Plateau. Scientific Reports, 7(1), 3845, DOI:10.1038/s41598-017-04140-7.

Lv, C.H., and Yu, B.H. (2011). The control technique and mode of land degradation in Qinghai-Tibet Plateau. Science Press, Beijing (in Chinese).

Manton, M.J., Della-Marta, P.M., Haylock, M.R., Hennessy, K.J., Nicholls, N., Chambers, L.E., Collins, D.A., Daw, G., Finet, A., Gunawan, D., Inape, K., Isobe, H., Kestin, T.S., Lefale, P., Leyu, C.H., Lwin, T., Maitrepierre, L., Ouprasitwong, N., Page, C.M., Pahalad, J., Plummer, N., Salinger, M.J., Suppiah, R., Tran, V.L., Trewin, B., Tibig, I., and Yee, D. (2001). Trends in extreme daily rainfall and temperature in Southeast Asia and the South Pacific: 1961-1998. International Journal of Climatology, 21, 269-284, DOI: 10.1002/joc.610.

McMichael, A., Woodruff, R., and Hales, S. (2006). Climate change and human health: present and future risks. The Lancet, 367, 859-869, D0I: 10.1016/S01406736(06)68079-3.

Mishra, V., Ganguly, A.R., Nijssen B., and Lettenmaier, D.P. (2015). Changes in observed climate extremes in global urban areas. Environmental Research Letters, 10(2), 024005, DOI: 10.1088/1748-9326/10/2/024005.

Moberg, A., Jones, P.D., Lister, D., Walther, A., Alexander, L.V., Brunet, M., Chen, D., Della-Marta, P.M., Jacobeit, J., Luterbacher, J., Yiou, P., Klein Tank, A.M.G., Almarza, C., Auer, I., Barriendos, M., Bergström, H., Böhm, R., Butler, J., Caesar, J., Drebs, A., Founda, D., Gerstengarbe, F.W., Giusi, M., Jónsson, T., Maugeri, M., Österle, H., Pandzic, K., Petrakis, M., Srnec, L., Tolasz, R., Tuomenvirta, H., Werner, P.C., Wanner, H., and Xoplaki, E. (2006). Indices for daily temperature and precipitation extremes in Europe analysed for the period 1901-2000. Journal of Geophysical Research, 111, D22106, D0I: 10.1029/2006JD007103.

New, M., Hewitson, B., Stephenson, D.B., Tsiga, A., and Lajoie, R. (2006). Evidence of trends in daily climate extremes over southern and west Africa. Journal of Geophysical Research: Atmosphere, 111, 3007-3021, DOI: 10.1029/2005JD006289.

Orlowsky, B., and Seneviratne, S.I. (2012). Global changes in extreme events: regional and seasonal dimension. Climatic Change, 110, 669-696, D0I: $10.1007 / \mathrm{s} 10584-011-0122-9$.

Pan, B., and Li, J. (1996). Qinghai-Tibetan Plateau: a driver and amplifier of the global climatic change. J. Lanzhou Univ. (Nat. Sci.) 32(1), 108-115 (In Chinese). DOI: 10.13885/j.issn.0455-2059.1996.01.024.

Patz, J.A., Campbell-Lendrum, D., Holloway, T., and Foley, J.A. (2005). Impact of regional climate change on human health. Nature, 438, 310-317, DOI: $10.1038 /$ nature04188.

Page 14/19 
Peterson, T.C., Folland, C., Gruza, G., Hogg, W., Mokssit, A., and Plummer, N. (2001). Report on the activities of the working group on climate change detection and related rapporteurs 1998-2001. Report WCDMP-47, WMO-TD 1071, World Meteorological Organization: Geneva, Switzerland.

Peterson, T.C., Taylor, M.A., Demeritte, R., Duncombe, D.L., Burton, S., Thompson, F., Porter, A., Mercedes, M., Villegas, E., Fils, R.S., Klein Tank, A.M.G., Martis, A., Warner, R., Joyette, A., Mills, W., Alexander, L., and Gleason, B. (2002). Recent changes in climate extremes in the Caribbean region. Journal of Geophysical Research, 107, 4601, DOI: 10.1029/2002JD002251.

Powell, E.J., and Keim, B.D. (2015). Trends in daily temperature and precipitation extremes for the southeastern United States: 1948-2012. Journal of Climate, 28, 1592-1612, DOI: 10.1175/JCLI-D-14-00410.1.

Revadekar, J.V., Hameed, S., Collins, D., Manton, M., and Shreshta, M.L. (2013). Impact of altitude and latitude on changes in temperature extremes over South Asia during 1971-2000. International Journal of Climatology, 33, 199-209, DOI: 10.1002/joc.3418.

Russo, S., and Sterl, A. (2011). Global changes in indices describing moderate temperature extremes from the daily output of a climate model. Journal of Geophysical Research, 116, D03104, DOI: 10.1029/2010JD014727.

Rusticucci, M., and Barrucand, M. (2004). Observed trends and changes in temperature extremes over Argentina. Journal of Climate, 17, 4099e4107, DOI: 10.1175/1520-0442(2004)0172.0.CO;2.

Serreze, M.C., Walsh, J.E., Chapin III, F.S., Osterkamp, T., Dyurgerov, M., Romanovsky, V., Oechel, W.C., Morison, J., Zhang, T. and Barry, R.G. (2000). Observational evidence of recent change in the northern high-latitude environment. Climatic Change, 46, 159-207, DOI: 10.1023/A:1005504031923.

Sillmann, J., Kharin, V.V., Zhang, X., Zwiers, F.W., and Bronaugh, D. (2013a). Climate extreme indices in the CMIP5 multi-model ensemble. Part 1: model evaluation in the present climate. Journal of Geophysical Research, 118, 1716-1733, DOI: 10.1002/jgrd.50203.

Sillmann, J., Kharin, V.V., Zhang, X., Zwiers, F.W., and Bronaugh, D. (2013b). Climate extreme indices in the CMIP5 multi-model ensemble. Part 2: future climate projections. Journal of Geophysical Research, 118, 2473-2493, DOI: 10.1002/jgrd.50188.

Skansi, M., Brunet, M., Sigró, J., Aguilar, E., Arevalo Groening, J.A., Bentancur, O.J., Castellón Geier, Y.R., Correa Amaya, R.L., Jácome, H., Malheiros Ramos, A., Oria Rojas, C., Pasten, A.M., Sallons Mitro, S., Villaroel Jiménez, C., Martínez, R., Alexander, L.V., and Jones, P.D. (2013). Warming and wetting signals emerging from analysis of changes in climate extreme indices over South America. Global and Planetary Change, 100, 295-307, DOI: 10.1016/j.gloplacha.2012.11.004.

Song, X., Song, S., Sun, W., Mu, X., Wang, S., Li, J., and Li, Y. (2015). Recent changes in extreme precipitation and drought over the Songhua River Basin, China, during 1960-2013. Atmospheric Research, 157, 137-152, DOI: 10.1016/j.atmosres.2015.01.022.

Sun, W., Mu, X., Song, X., Wu, D., Cheng, A., and Qiu, B. (2016). Changes in extreme temperature and precipitation events in the Loess Plateau (China) during 1960-2013 under global warming. Atmospheric Research, 168, 33-48. DOI: 10.1016/j.atmosres.2015.09.001.

Supari, S., Tangang, F., Liew, J., and Aldrian, E. (2017). Observed changes in extreme temperature and precipitation over Indonesia. International Journal of Climatology, 37, 1979-1997, DOI: 10.1002/joc.4829.

Tabari, H., Shifteh Somee, B., and Rezaeianzadeh, M. (2011). Testing for long-term trends in climatic variables in Iran. Atmospheric Research, 100, 0-140, DOI: 10.1016/j.atmosres.2011.01.005.

Tebaldi, C., Hayhoe, K., Arblaster, J. M., and Meehl, G. A. (2006). Going to the extremes: an intercomparison of model simulated historical and future changes in extreme events. Climatic Change, 79, 185-211, DOI: 10.1007/s10584-006-9051-4.

Thornton, P.K., Ericksen, P.J., Herrero, M., and Challinor A.J. (2014). Climate variability and vulnerability to climate change: a review. Global Change Biology, 20, 3313-3328, DOI: $10.1111 / \mathrm{gcb} .12581$.

Viola, F., Liuzzo, L., Noto, L., Conti, F., and la Loggia, G. (2014). Spatial distribution of temperature trends in Sicily. International Journal of Climatology, 34, 1-17, DOI: $10.1002 /$ joc.3657.

Wang, G., Bai, W., and Hu, H. (2011). Climate changes and its impact on tundra ecosystem in Qinghai-Tibet Plateau, China. Climatic Change, 106, 463-482, DOI: $10.1007 / \mathrm{s} 10584-010-9952-0$.

Wang, Q., Zhang, M., Wang, S., Ma, Q., and Sun, M. (2014). Changes in temperature extremes in the Yangtze River Basin, 1962-2011. Journal of Geographical Sciences, 24 (1), 59-75, DOI: 10.1007/s11442-014-1073-7.

Wang, W., Shao, Q., Yang, T., Peng, S., Yu, Z., Taylor, J., Xing, W., Zhao C., and Sun, F. (2012). Changes in daily temperature and precipitation extremes in the Yellow River Basin, China. Stochastic Environmental Research and Risk Assessment, 27(2), 401-421, D0I: 10.1007/s00477-012-0615-8.

Wang, X., Li, Y., Wang, M., Li, Y., Gong, X., Chen, Y.P., Chen, Y., and Cao, W. (2020). Changes in daily extreme temperature and precipitation events in mainland China from 1960 to 2016 under global warming. International Journal of Climatology, 2020, 1-19, DOI: 10.1002/joc.6865.

Wang, X.L. (2008a). Accounting for autocorrelation in detecting mean shifts in climate data series using the penalized maximal t or F test. Journal of Applied Meteorology and Climatology, 47, 2423-2444, DOI: 10.1175/2008JAMC1741.1.

Page $15 / 19$ 
Wang, X.L. (2008b). Penalized maximal F test for detecting undocumented mean shift without trend change. Journal of Atmospheric and Oceanic Technology, 25, 368-384, DOI: 10.1175/2007JTECHA982.1.

Wang, X.L., Wen, Q.H., and Wu, Y. (2007). Penalized maximal t test for detecting undocumented mean change in climate data series. Journal of Applied Meteorology and Climatology, 46, 916-931, DOI: 10.1175/JAM2504.1.

Wang, X.Y., Li, Y., Chen, Y., Lian, J., Luo, Y., Niu, Y., Gong, X., and Yu, P. (2018). Temporal and spatial variation of extreme temperatures in an agro-pastoral ecotone of northern China from 1960 to 2016. Scientific Reports, 8, 8787, DOI:10.1038/s41598-018-27066-0.

Xu, W., and Liu, X. (2007). Response of vegetation in the Qinghai-Tibet Plateau to global warming. Chinese Geographical Science, 17(2), 151-159, DOI: $10.1007 /$ s11769-007-0151-5.

Yan, H.M., Chen, W.N., Yang, F.X., Liu, J.Y., and Ji, Y.Z. (2014). The spatial and temporal analysis of extreme climatic events in Inner Mongolia during the past 50 years. Geographical Research, 33, 14-22, DOI: 10.11821/dlyj201401002.

You, Q., Kang, S., Aguilar, E., Pepin, N., Flügel, W.-A., Yan, Y., Xu, Y., Zhang, Y., and Huang, J. (2011). Changes in daily climate extremes in China and their connection to the large scale atmospheric circulation during 1961-2003. Climate Dynamics, 36(11-12), 2399-2417, DOI 10.1007/s00382-009-0735-0.

Zhang, C.L., Li, Q., Shen, Y.P., Zhou, N., Wang, X.S., Li, J., and Jia, W.R. (2017). Monitoring of aeolian desertification on the Qinghai-Tibet Plateau from the 1970s to 2015 using Landsat images. Science of the Total Environment, 619-620, 1648-1659. DOI: 10.1016/j.scitotenv.2017.10.137.

Zhang, X., Aguilar, E., Sensoy, S., Melkonyan, H., Tagiyeva, U., Ahmed, N., Kutaladze, N., Rahimzadeh, F., Taghipour, A., Hantosh, T.H., Albert, P., and Semawi, M. (2005). Trends in Middle East climate extreme indices from 1950 to 2003. Journal of Geophysical Research, 110, D22104, DOI: 10.1029/2005JD006181.

Zhang X., and Yang F. (2004). RClimDex (1.0) User Guide. Climate Research Branch, Environment Canada: Downsview, Ontario, Canada.

Zhang, Y., Wang, G., and Wang, Y. (2010). Response of biomass spatial pattern of alpine vegetation to climate change in permafrost region of the QinghaiTibet Plateau, China. Journal of Mountain Science, 7(04), 301-314, DOI: 10.1007/s11629-010-2011-5.

Zhang, Z., Han, W., Wang, J., Cai, Y., Li, G., Cai, Z., Zhang, C., Sheng, H., and Zhao, C. (2016). Characteristics of climate change and its response in the QinghaiTibet Plateau during 1971-2010. Journal of Landscape Research, 8(6), 41-45, 52, DOI: 10.16785/j.issn 1943-989x.2016.6.011. (In Chinese)

Zhen, Y., and Li, X. (2014). Recent trends in daily temperature extremes over northeastern China (1960-2011). Quaternary International, 380-381, 35-48 DOI: 10.1016/j.quaint.2014.09.010.

Zheng, D. (1996). The system of physico-geographical regions of the Qinghai-Xizang (Tibet) Plateau. Science in China (Series D), 39(4), 410-417, D0I: 10.1144/GSL.QJEGH.1996.029.P3.08. (In Chinese)

Zheng, D. (1999). A study on the physico-geographical regional system of the Tibetan Plateau. Science in China (Ser. D) 26 (4), $336-341$ (In Chinese), D0I: 10.13249/j.cnki.sgs.1999.04.002.

Zhong, K., Zheng, F., Wu, H., Qin, C., and Xu, X. (2017). Dynamic changes in temperature extremes and their association with atmospheric circulation patterns in the Songhua River Basin, China. Atmospheric Research, 190, 77-88, DOI: 10.1016/j.atmosres.2017.02.012.

Zhao, Z. \& Wang, Y. Influence of the West Pacific subtropical high on surface ozone daily variability in summertime over eastern China. Atmos. Environ. 170, 197-204 (2017).

\section{Figures}




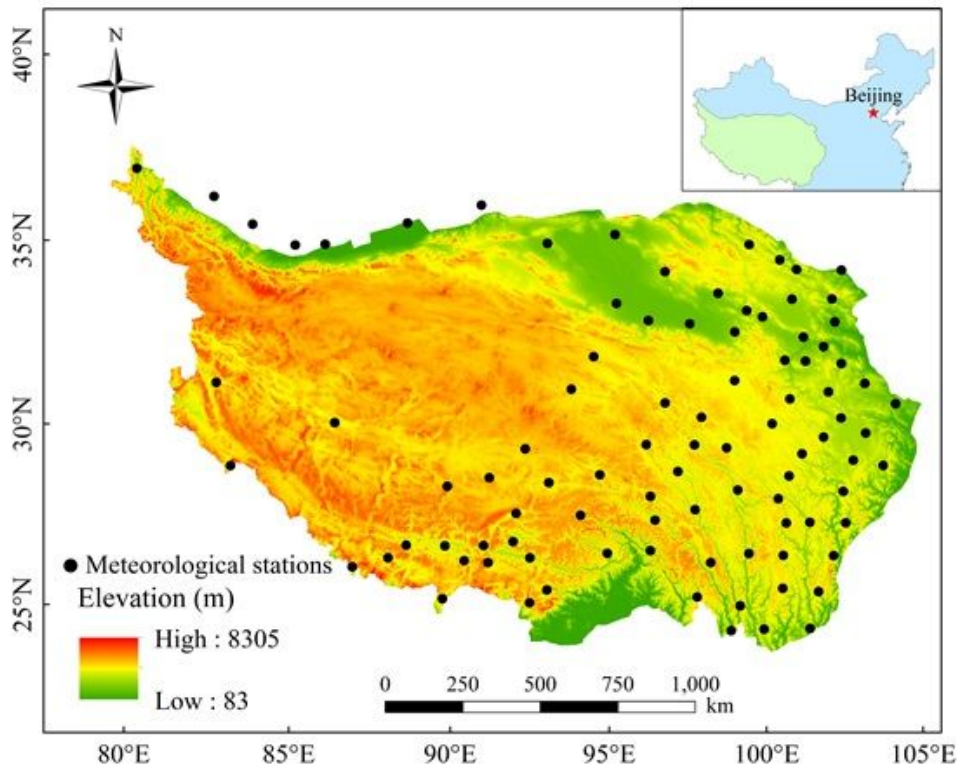

Figure 1

Study area and the distribution of meteorological stations. A total of 89 meteorological stations were located within the Qinghai-Tibet Plateau, and 5 stations were in areas surrounding the plateau. Note: The designations employed and the presentation of the material on this map do not imply the expression of any opinion whatsoever on the part of Research Square concerning the legal status of any country, territory, city or area or of its authorities, or concerning the delimitation of its frontiers or boundaries. This map has been provided by the authors.
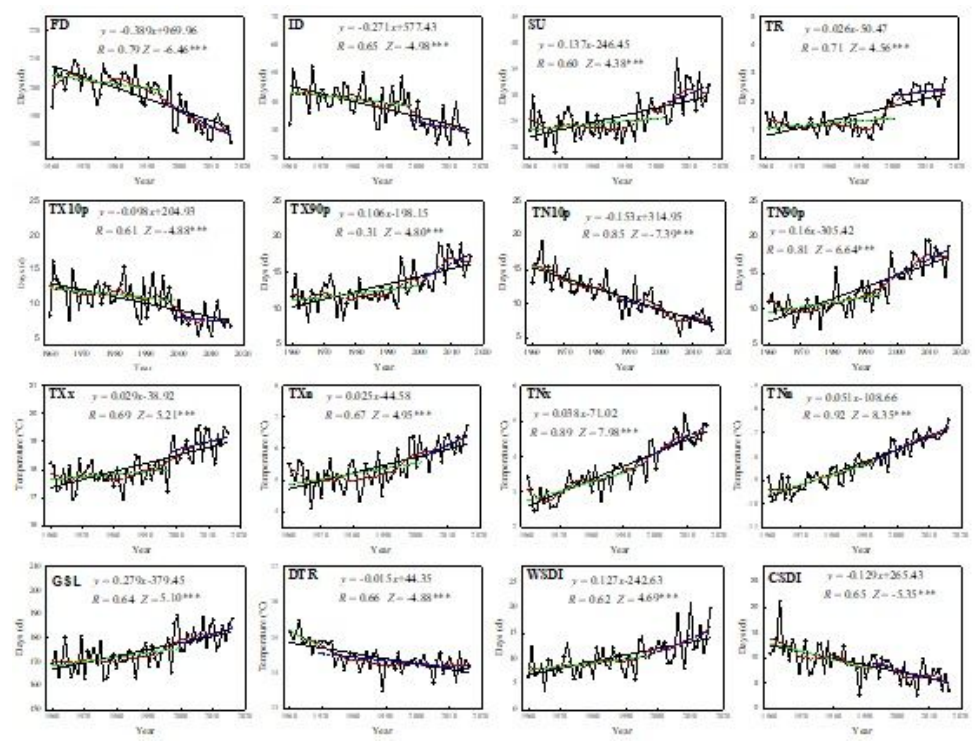

Figure 2

Regionally averaged time series for indices of the extreme temperature events on the Qinghai-Tibet Plateau from 1960 to 2016. The indices are defined in Table 1. Straight lines represent statistically significant linear regressions; the dashed red line is the smoothed 10-year running average, the dashed green and blue line are linear regressions before and after abrupt years, respectively. Z scores represent the Mann-Kendall test results. Significance: $* \star \star, P<0.001$. 


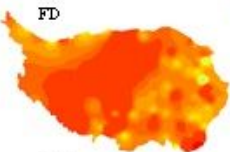

Txlop

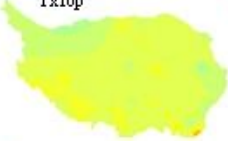

TXX

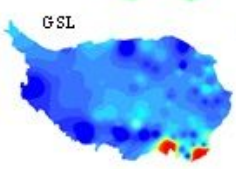

ID

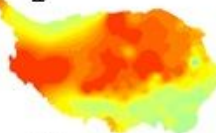

Txoop

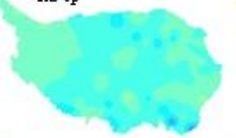

$\mathrm{TXn}$

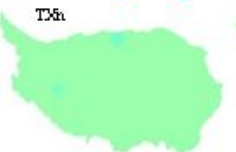

DTR
SU

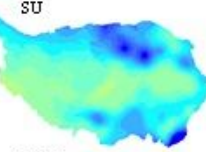

TN10p

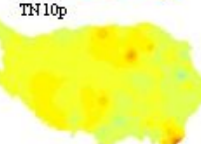

TNX

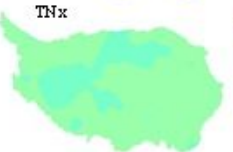

WSDI

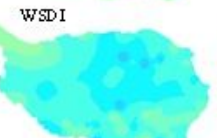

TR

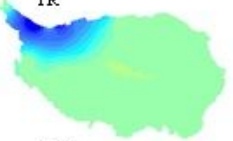

TN90

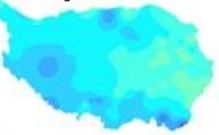

$\mathrm{THn}$

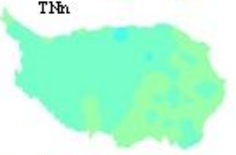

CSDI

Slope

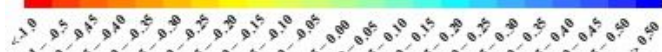

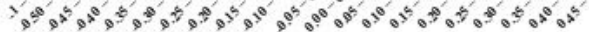

Figure 3

Spatial pattern of the trends for temperature indices from the 94 meteorological stations in the Qinghai-Tibet Plateau from 1960 to 2016 . The indices are defined in Table 1. Note: The designations employed and the presentation of the material on this map do not imply the expression of any opinion whatsoever on the part of Research Square concerning the legal status of any country, territory, city or area or of its authorities, or concerning the delimitation of its frontiers or boundaries. This map has been provided by the authors.
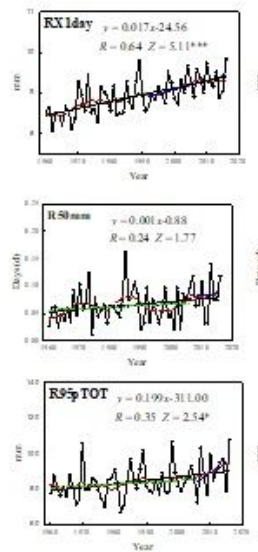
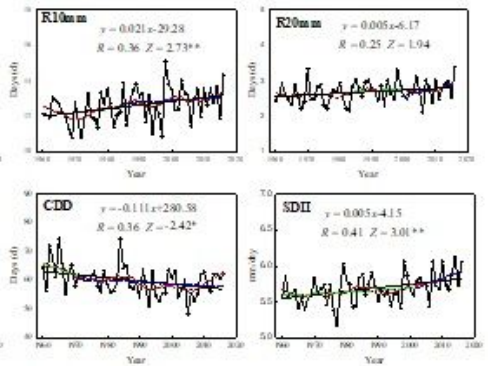

\section{Figure 4}

Regionally averaged series for the extreme precipitation indices in the Qinghai-Tibet Plateau from 1960 to 2016 . The indices are defined in Table 1. Straight lines represent linear regressions; the dashed red line is the smoothed 10-year running average, the dashed green and blue line are linear regressions before and after abrupt years, respectively. Z scores represent the Mann-Kendall test results for the strength of the trend. Significance: ***, $\mathrm{P}<0.001 ; * \star, P<0.01 ; *, \mathrm{P}<$ 0.05. All other results are not significant.
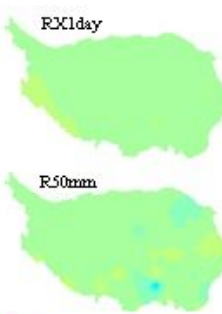

Rosp TOT

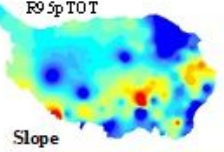

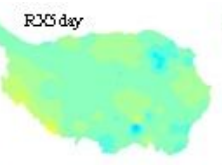

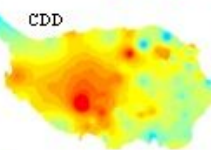

R9p TOT
R10mm

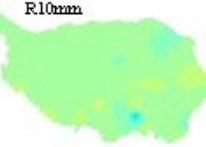

CWD

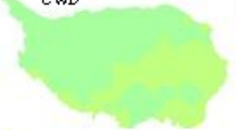

PRCP TOT $-0.616 x-72.63$ then

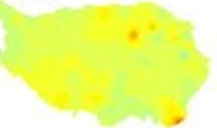


Figure 5

Spatial pattern of the trends for precipitation indices from the 94 meteorological stations in the Qinghai-Tibet Plateau from 1960 to 2016 . The indices are defined in Table 1. Note: The designations employed and the presentation of the material on this map do not imply the expression of any opinion whatsoever on the part of Research Square concerning the legal status of any country, territory, city or area or of its authorities, or concerning the delimitation of its frontiers or boundaries. This map has been provided by the authors. 